
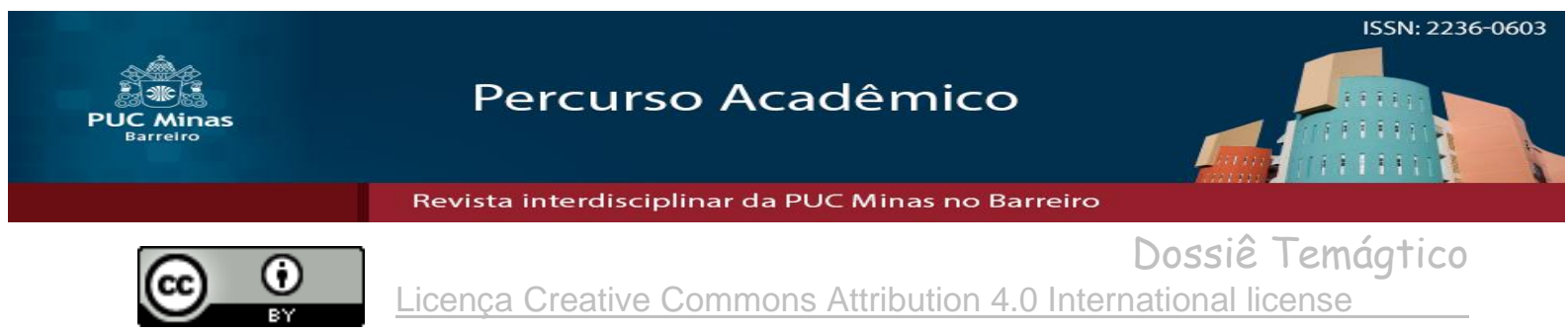

\title{
Planejamento para renda passiva pós-emprego por meio de gestão independente de investimentos: caso para ensino
}

\author{
Planning for passive post-employment income through independent investment management: \\ case for teaching \\ Manoel Cândido de Lima Ramos ${ }^{1}$ \\ Wanderson Wadjô Mendonça de Resende ${ }^{2}$ \\ Alexandre Magno da Silva ${ }^{3}$ \\ Daniel José Pimenta ${ }^{4}$ \\ Sidney Lino Oliveira ${ }^{5}$
}

\section{RESUMO}

O presente caso para ensino tem como objetivo propiciar uma reflexão acerca da importância de um planejamento financeiro de longo prazo, visando a obtenção de uma futura renda passiva pós-emprego sustentada por retorno de investimentos proveniente de uma gestão própria, com foco nos jovens que estão iniciando a vida profissional e permitindo um debate sobre finanças pessoais. O perfil do indivíduo ilustrado neste caso é o de um estudante que possui 25 anos, ainda mora com os pais, está ingressando no mercado de trabalho, tem pouco conhecimento em educação financeira, nunca se organizou financeiramente, tampouco realizou controle de gastos, contudo, tem interesse em assuntos relacionados a poupança e investimentos. Assim, a proposta é que os leitores se coloquem no papel deste estudante, e façam uma análise das propostas apresentadas para a alocação de suas reservas financeiras em um plano estruturado para obter sua renda passiva pós-emprego, bem como permitir um debate sobre a importância a respeito do conhecimento sobre finanças pessoais para estabelecer um bom equilíbrio e saúde financeira ao longo da vida. $\mathrm{O}$ caso foi elaborado para utilização em cursos com disciplinas que abordam os assuntos de controle financeiro, finanças pessoais ou orçamentos, com objetivo de aprimoramento do aprendizado.

Palavras-chave: Renda Passiva, Planejamento financeiro, Pós-Emprego.

\begin{abstract}
The present case for teaching aims to provide a reflection on the importance of long-term financial planning, aiming at obtaining a future passive post-employment income sustained by return on investment from its own management, focusing on young people who are starting professional life and allowing a debate about personal finances. The profile of the individual illustrated in this case is that of a student who is 25 years old, still lives with his parents, is entering the job market, has little knowledge of financial education, has never organized himself financially, nor has he carried out expenditure control, however, is interested in matters related to savings and investments. Thus, the proposal is that the readers put themselves in the role of this student, and make an analysis of the proposals presented for the allocation of their financial reserves in a structured plan to obtain their passive post-employment income, as well as allowing a debate on the importance about knowledge about
\end{abstract}

Artigo recebido em 13 de setembro de 2021 e aprovado em 04 de dezembro de 2021

${ }^{1}$ Graduando do curso de Ciências Contábeis (PUC Minas), Brasil. E-mail: manelcandido@gmail.com

${ }^{2}$ Graduando do curso de Ciências Contábeis (PUC Minas), Brasil. E-mail: wwmresende@gmail.com

${ }^{3}$ Graduando do curso de Ciências Contábeis (PUC Minas), Brasil. E-mail: almagno1921@yahoo.com.br

${ }^{4}$ Graduando do curso de Ciências Contábeis (PUC Minas), Brasil. E-mail: pimenta@seupatrimonio.com.br

${ }^{5}$ Doutor em Administração (UFMG), Docente (PUC Minas), Brasil. E-mail: sidneylino@pucminas.br 
personal finance to establish a good balance and financial health throughout life. The case was designed for use in courses with disciplines that address the subjects of financial control, personal finances or budgets, with the objective of improving learning.

Keywords: Financial planning. Passive Income. Post-Employment.

\section{INTRODUÇÃO}

Belo Horizonte, terça-feira, às vinte horas e cinquenta minutos, João, que acaba de completar 25 anos, aluno do curso de Ciências Contábeis, estava conversando com sua amiga Laura no intervalo, enquanto aguardava a próxima aula. Ele estava em uma situação nova e desafiadora, conseguiu seu primeiro emprego em uma empresa, porém incipiente na vida profissional, João gostaria de lidar melhor com o dinheiro que receberia como salário. $\mathrm{O}$ estudante dispunha de pouco conhecimento relativo à educação financeira, e gostaria de conhecer mais sobre planejamentos de longo prazo e a única coisa que ele afirmava com segurança é que gostaria de parar de trabalhar aos 60 anos e poder viver o resto da vida com estabilidade financeira, sem depender da previdência social.

\section{ANTECEDENTES}

João nunca teve que se preocupar com assuntos relacionados a finanças e orçamentos, pois sempre morou com os pais e todas as suas necessidades foram supridas e sua preocupação limitava-se a pequenos gastos do dia a dia. Em 2018, iniciou a graduação em Ciências Contábeis e, já na segunda metade do curso, teve a oportunidade de participar de um programa de estágio não remunerado na área de controladoria em uma multinacional, onde executava atividades relacionadas a fechamento contábil, controle de verba e orçamento previsto versus realizado. Iniciou-se neste período seu interesse pela área financeira, tanto que João, ao desempenhar suas funções com muita dedicação e apresentar bons resultados, motivou a empresa a investir no seu talento, efetivando sua contratação.

\section{O INÍCIO DA INDEPENDÊNCIA}

João sempre teve o objetivo de se tornar independente, ter seu próprio estilo de vida e consequentemente morar sozinho, mas encontrava-se totalmente inseguro pois sempre esteve sob a tutela dos pais e nunca se atentou para a oportunidade de participar dos problemas que envolvem um planejamento financeiro e orçamento familiar. No entanto, o estágio na área de controladoria lhe despertou o interesse para o assunto de finanças e logo ele percebeu que precisava aplicar aqueles exemplos em sua vida, planejando-a de forma similar aos planos que teve oportunidade de acompanhar no ambiente corporativo. Assim, João, que nunca possuiu uma fonte de renda, nunca precisou se organizar financeiramente e nunca fez controle dos gastos, deparou-se com um horizonte totalmente novo. Com base neste cenário, ele entendeu que aquele momento seria o marco de uma completa mudança de atitudes que fariam diferença 
no decorrer de toda a sua vida. Desta forma, João buscou conhecimento para elaborar um planejamento orçamentário pessoal e desenvolver comportamentos financeiros que o levassem a uma situação de equilíbrio e saúde financeira. $\mathrm{O}$ foco inicial foi conseguir identificar com o que gastava e o quanto gastava para melhorar a gestão dos seus recursos. $\mathrm{O}$ estudante foi então instruído a evitar dívidas, controlar seus gastos e economizar parte de sua receita mantendo uma reserva emergencial e alocando suas economias em investimentos bem planejados. Assim, por meio dessa gestão independente de suas aplicações, ele espera que no futuro estes investimentos possam lhe proporcionar uma renda passiva, dando-lhe conforto e segurança financeira em seu período pós-emprego.

\section{EM BUSCA DAS ESTRATÉGIAS DE INVESTIMENTO}

Em sua busca por conhecimento na área de investimentos João entendeu que o planejamento financeiro seria crucial para atingir seus objetivos, sendo que este planejamento resumia-se basicamente em evitar dívidas com pagamento de juros, constituir uma reserva de emergência para gastos extraordinários e direcionar um percentual de sua renda ativa para investimentos, com o objetivo de, no futuro, obter uma remuneração sobre este capital acumulado ao longo dos anos.

Para se atingir um montante de capital suficiente para gerar a renda passiva após seu período ativo, é necessário conhecer o que há de oportunidades de investimento no mercado, suas características, sua liquidez, tributação, custos, retorno e os riscos envolvidos.

João, com o seu pouco de conhecimento sobre o mercado financeiro, buscou informações na internet e encontrou muito conteúdo interessante, principalmente em sites de instituições renomadas como ANBIMA (Associação Brasileira das Entidades do Mercado Financeiro), B3 (Brasil, Bolsa, Balcão) e CVM (Comissão de Valores Mobiliários). João centrou sua pesquisa em investimentos direcionados para iniciantes, em diversas fontes disponíveis, e elaborou uma tabela simplificada que facilitasse sua análise, conforme apresentado na Tabela 1 . 
Tabela 1 - Alguns exemplos de investimentos

\begin{tabular}{|c|c|c|c|}
\hline Tipo & Principais opções & Descrição breve & $\begin{array}{l}\text { Principais } \\
\text { características }\end{array}$ \\
\hline \multirow{6}{*}{$\begin{array}{l}\text { Renda } \\
\text { Fixa }\end{array}$} & $\begin{array}{l}\text { CDB - Certificado de } \\
\text { depósito interbancário }\end{array}$ & É um empréstimo que se faz para um banco. & Baixo risco \\
\hline & $\begin{array}{l}\text { LCI - Letras de crédito } \\
\text { imobiliário }\end{array}$ & $\begin{array}{l}\text { Empréstimo para financiar o setor imobiliário. É } \\
\text { isento de imposto de renda. O risco está atrelado à } \\
\text { instituição emissora. }\end{array}$ & $\begin{array}{l}\text { Isento de Imposto } \\
\text { de Renda }\end{array}$ \\
\hline & $\begin{array}{l}\text { LCA - Letras de crédito } \\
\text { da agricultura }\end{array}$ & $\begin{array}{l}\text { Empréstimo para financiar o setor de agricultura. É } \\
\text { isento de imposto de renda. O risco está atrelado à } \\
\text { instituição emissora. }\end{array}$ & $\begin{array}{l}\text { Isento de Imposto } \\
\text { de Renda }\end{array}$ \\
\hline & Tesouro Direto & $\begin{array}{l}\text { Empréstimo para o governo. Cabe ressaltar que o } \\
\text { governo é considerado o emissor mais seguro de uma } \\
\text { economia. }\end{array}$ & Baixíssimo risco \\
\hline & ETF de renda fixa & $\begin{array}{l}\text { É um fundo que segue um indicador, ou seja, tem } \\
\text { uma gestão passiva. São negociados em bolsa. }\end{array}$ & Baixo risco \\
\hline & Debêntures & $\begin{array}{l}\text { O investidor compra a dívida de empresas privadas, } \\
\text { que devolvem o dinheiro acrescido de juros. O risco é } \\
\text { o de a companhia não cumprir com o pagamento da } \\
\text { aplicação, e isso pode acontecer por diferentes } \\
\text { motivos, inclusive falência. }\end{array}$ & $\begin{array}{l}\text { O tipo chamado de } \\
\text { "debêntures } \\
\text { incentivadas", são } \\
\text { isentas de imposto } \\
\text { de renda e IOF. }\end{array}$ \\
\hline \multirow{4}{*}{$\begin{array}{l}\text { Renda } \\
\text { Variável }\end{array}$} & Ações; BDRs & $\begin{array}{l}\text { O investidor negocia um percentual de participação } \\
\text { em uma empresa de capital aberto. São negociadas na } \\
\text { bolsa e estão sujeitas a grandes oscilações de preço. }\end{array}$ & $\begin{array}{l}\text { Alta volatilidade, } \\
\text { portanto, alto risco }\end{array}$ \\
\hline & $\begin{array}{l}\text { Fundos de investimento } \\
\text { em ações }\end{array}$ & $\begin{array}{l}\text { São uma opção para quem deseja investir na Bolsa de } \\
\text { Valores, mas não quer comprar ações de forma direta } \\
\text { e de uma determinada empresa. Tem boa } \\
\text { diversificação, porém paga-se taxas de administração. }\end{array}$ & Diversificação \\
\hline & ETF de renda variável & $\begin{array}{l}\text { São fundos de investimento em ações negociados na } \\
\text { Bolsa de Valores. }\end{array}$ & Diversificação \\
\hline & $\begin{array}{l}\text { FII - Fundos de } \\
\text { investimento imobiliário }\end{array}$ & $\begin{array}{l}\text { Negociação de cotas de grandes empreendimentos, } \\
\text { como hotéis, shoppings e salas comerciais. São } \\
\text { negociados na Bolsa de Valores. }\end{array}$ & $\begin{array}{l}\text { Dividendos } \\
\text { mensais com } \\
\text { isenção de imposto } \\
\text { de renda }\end{array}$ \\
\hline
\end{tabular}

Fonte: Elaborado pelos autores com base em informações extraídas dos sítios b3.com.br e xpi.com.br

João, em suas pesquisas, aprendeu que cada pessoa tem um determinado perfil como investidor, e que esses perfis estão diretamente ligados a como as pessoas lidam com os riscos. 
Segundo a teoria, encontrada no site da XP Investimentos (2021), os perfis de investidores são três, a saber: o Perfil Conservador, que busca manter o capital conquistado garantindo retornos de títulos com baixo risco e com maior liquidez no mercado, o Perfil Moderado, que evita exposições excessivas e busca manter equilíbrio entre bons retornos do mercado e riscos controlados e o Perfil Agressivo, que busca os maiores retornos do mercado, expondo-se a riscos proporcionalmente altos.

Após seu breve estudo do mercado financeiro, João pôde perceber que há risco em qualquer tipo de investimento, que as possibilidades de retorno estão diretamente ligadas a esses riscos e que suas escolhas de investimentos deveriam ser adequadas ao seu perfil, ao montante a ser aplicado e às circunstâncias em que os investimentos são feitos, como por exemplo o tempo em que se pretende manter cada aplicação e as taxas de retorno. Ficou claro para ele que sua reserva de emergência deveria ser alocada em um tipo de investimento com menor risco e maior liquidez, mesmo que não obtivesse grandes retornos, pois poderia necessitar deste valor a qualquer momento. Então, definiu que manteria uma quantia de aproximadamente seis remunerações mensais como reserva emergencial, aplicada em renda fixa de liquidez diária para lhe dar garantia em caso de imprevistos e o restante deveria ser dividido entre renda fixa, com menor risco, e renda variável, opção mais arriscada, buscando uma taxa média de retorno adequada, com risco controlado.

João continuou sua busca por conhecimento e pesquisou mais sobre o assunto, encontrando discussões que lhe chamaram a atenção para a denominada "regra dos 80" (MONEYTIMES, 2021), que é uma metodologia de alocação de investimentos e controle de riscos que funciona da seguinte forma: para utilizá-la, o investidor deve subtrair a sua idade atual de 80, o resultado obtido então, demonstra qual a porcentagem do seu capital deve ser alocado em renda variável e o restante deve ser alocado em renda fixa. Dessa forma, seguindo a "regra dos 80", uma pessoa de 25 anos, por exemplo, deverá aplicar 55\% de seu capital em renda variável e o que sobrar deve ser alocado em investimentos de renda fixa, para que assim possa ter um certo controle sobre o risco na carteira. Pela "regra dos 80", à medida que o tempo passa, os valores vão migrando da renda variável para a renda fixa até que, ao atingir 80 anos, a pessoa terá todo o seu montante de investimentos alocado em renda fixa.

João então percebeu que isso fazia muito sentido, pois, de acordo com suas pesquisas, as pessoas mais jovens podem assumir maiores riscos por ainda terem pela frente tempo suficiente para corrigir desvios no planejamento e como os investimentos mais arriscados estão sujeitos a taxas de retorno maiores, tornam-se uma grande oportunidade para alavancar o patrimônio. Por outro lado, pessoas com idade mais avançada precisam de maior segurança, pois, se já não dependem do patrimônio investido para viver, estão próximos desta condição e, portanto, não há tempo suficiente para correções de planejamento e recuperação de eventuais perdas, por isso, devem alocar suas reservas em investimentos de menor risco, como os de renda fixa. Além disso, João percebeu que as pessoas com idade mais avançada e que se planejaram financeiramente para o pós-emprego, chegam a esse momento da vida com um bom patrimônio investido e por isso não dependem de altas taxas de retorno para terem sua 
renda passiva garantida, sendo suficientes as alocações em renda fixa que lhes dão grande tranquilidade.

Quanto mais João estudava sobre finanças pessoais e estratégias de investimentos, mais fascinado ficava com o assunto. João percebeu como os juros compostos poderiam transformar suas economias em uma quantia que lhe desse segurança ao longo do tempo. Quanto mais jovem a pessoa decide começar a investir, mais tempo seus investimentos estarão sujeitos aos efeitos dos juros sobre juros, contribuindo para a construção de um patrimônio sólido que poderá lhe trazer a tão sonhada independência financeira. João, então, se convenceu que estava no caminho certo e mesmo ainda no início da carreira, ele deveria pensar em formas de construir seu patrimônio, aos poucos, para que o seu futuro fosse próspero.

Outra coisa que João aprendeu com seus estudos foi a importância da diversificação como forma de controlar os riscos. Poupar dinheiro requer bastante esforço, ainda mais na sociedade consumista em que vivemos nos dias de hoje, por isso, todo o dinheiro poupado deve ser investido com muito critério para defendê-lo de perdas que possam arruinar o planejamento. Um dos meios de se proteger é construir um portfólio de investimentos diversificado, para que no caso de eventuais perdas em uma linha de investimentos, haja uma compensação com ganhos em outra, mantendo-se assim uma taxa média de retorno próxima ao planejado.

Contudo, antes de montar a sua carteira de investimentos João ainda precisava definir os seus anseios para o futuro, pois seria a partir deles que ele saberia qual o percentual da renda ativa seria destinado aos investimentos para que conseguisse atingir o montante suficiente para dar-lhe a tão sonhada renda passiva em seu pós-emprego. João então procurou a Liga Financeira da sua faculdade, que é um grupo que se dedica ao estudo do mercado financeiro e finanças pessoais, para melhores esclarecimentos e para obter ajuda com essas questões. Conversando com os consultores da Liga, João percebeu que eles utilizavam planilhas que possibilitavam a montagem de alguns cenários distintos considerando o perfil de pessoas que buscam atingir independência financeira por meio de gestão própria de seus recursos. As planilhas foram desenvolvidas com cálculos iterativos solucionados por meio de código VBA do Excel. Todavia, primeiramente João deveria refletir sobre as suas metas e objetivos que seriam os dados de entrada para simular as possibilidades.

Neste caso, ele deveria definir ou fazer uma estimativa dos seguintes parâmetros: Idade para iniciar o plano de acumulação de capital, idade que gostaria de parar de trabalhar e passar a viver de renda passiva, expectativa de vida, o montante da reserva de emergência que ele gostaria de manter em termos de quantidade de meses de salário, uma estimativa da taxa média de retorno esperada ao ano, se haverá algum tipo de aporte inicial e a expectativa da taxa de atualização da sua renda ao ano.

João foi informado que as planilhas eram totalmente flexíveis e que poderiam ser ajustadas ao longo do tempo caso a situação dele se alterasse ou fosse preciso ajustar algum parâmetro, mas era preciso que João escolhesse um dos cenários para pautar e subsidiar os seus objetivos sabendo que a escolha de um ou outro cenário demandaria um esforço menor 
ou maior no percentual da renda ativa que seria destinado aos investimentos. Os cenários apresentados pelos consultores foram os seguintes:

Cenário 1: João, em seu pós-emprego, iniciaria com uma renda passiva no valor igual ao seu último salário líquido e esta iria se reduzindo, ano a ano, à mesma taxa da progressão salarial considerada em sua fase ativa. O montante de capital também se reduziria gradativamente até chegar a zero ao atingir a expectativa de vida considerada no planejamento, cessando assim a sua renda.

Cenário 2: João teria uma renda passiva com valor igual ao seu último salário líquido na fase ativa, porém, o montante de capital iria sendo consumido até chegar a zero ao atingir a idade pré-estabelecida como expectativa de vida no planejamento, cessando assim sua renda. Neste cenário ele contaria com um salário líquido na fase ativa um pouco menor que no Cenário 1, para compensar a manutenção da renda passiva com o mesmo valor do último salário líquido, sem reduções.

Cenário 3: João teria uma renda passiva com valor igual ao seu último salário líquido na fase ativa e manteria também o montante de capital acumulado ao longo de todo a sua fase ativa, sendo que a renda passiva estaria garantida apenas pelos juros, não consumindo o montante de capital. Neste caso, contudo, João teria que desembolsar um percentual de sua renda ativa maior do que nos Cenários 1 e 2, para formar o montante de capital suficiente, obrigando João a um maior esforço de economia.

João, portanto, entusiasmado com as possibilidades, perguntou aos consultores se era possível realizar uma simulação para que pudesse enxergar as alternativas com mais clareza e pudesse tomar uma decisão com base nesta análise. Os consultores disseram que era perfeitamente possível e em conjunto com ele estabeleceram as premissas de entrada para a simulação. Assim, os dados de entrada para as planilhas foram listados na Tabela 2.

Tabela 2 - Premissas do João para o plano de renda passiva pós-emprego

\begin{tabular}{|l|r|}
\hline Premissas definidas & Valor \\
\hline Idade para iniciar o plano de renda passiva pós-emprego: & 25 \\
\hline Idade para iniciar a renda passiva: & 60 \\
\hline Expectativa de vida: & 80 \\
\hline Reserva de Emergência (meses): & 6 \\
\hline Taxa média de retorno esperada (ao ano): & $5,0 \%$ \\
\hline Aporte inicial: & 0,00 \\
\hline Salário inicial (líquido na conta bancária): & $3.140,46$ \\
\hline Taxa de atualização da renda (ao ano): & $2,0 \%$ \\
\hline
\end{tabular}

Fonte: Elaborado pelos autores 
O formando afirmou que após o estágio teria um salário inicial de $\mathrm{R} \$ 3.140,46$ (Três mil, cento e quarenta reais e quarenta e seis centavos), já líquidos dos descontos em folha e que não tinha disponível recursos para realizar aporte inicial. João também afirmou que gostaria de iniciar sua renda passiva aos 60 anos de idade e que o plano de acúmulo de capital deveria considerar início imediato, ou seja, aos 25 anos.

Para a definição da expectativa de vida, os consultores apresentaram ao João os dados informados pela Agência IBGE Notícias (IBGE, 2020), que indicam que uma pessoa nascida no Brasil em 2019 tinha expectativa de viver, em média, até os 76,6 anos, sendo que a expectativa de vida para homens era de 73,1 anos e para as mulheres era de 80,1 anos. Os consultores explicaram para João que a expectativa de vida do brasileiro vem aumentando a cada ano e o aconselharam a utilizar uma expectativa de vida de 80 anos para a simulação dos cenários. Foi colocado também que tal escolha teria impacto direto nos cálculos dos Cenários 1 e 2, pois nesses dois cenários o planejamento considera o consumo do montante acumulado, zerando-o na expectativa de vida estabelecida, mas que seria quase indiferente no Cenário 3 , pois neste cenário a renda passiva é garantida apenas pelos juros do capital acumulado e, portanto, tem-se uma projeção desta renda para a posteridade, independente de quantos anos a pessoa viver. O único impacto causado pela escolha da expectativa de vida no Cenário 3 seria na alocação dos investimentos, pois as planilhas foram elaboradas utilizando-se uma adaptação da "regra dos 80 ", onde o valor 80 é substituído pela expectativa de vida informada no plano. Os consultores alertaram João que uma reserva de emergência com valor em torno de 6 meses de salário seria o ideal, e a constituição de tal reserva deveria ser sua prioridade, mantendo-a em investimentos de baixo risco e liquidez diária, para garantir suas necessidades de curto prazo.

Após constituir sua reserva de emergência, deveria então direcionar suas economias para os investimentos em renda fixa e renda variável, conforme planejamento de alocação estabelecido pela "regra dos 80 ", buscando uma taxa média de retorno ao ano de $5 \%$ acima da inflação. Neste ponto, cabe ressaltar que o valor alocado na reserva de emergência não faz parte da distribuição entre renda fixa e renda variável estabelecida pela "regra dos 80 ”, mas é contabilizada no montante para estabelecimento da renda passiva no futuro. A taxa média de atualização da renda ativa foi estipulada em $2 \%$ ao ano.

Após lançar os dados nas planilhas, chegou-se aos cenários prováveis para o pós-emprego de João. As planilhas com os dados ano a ano foram apresentadas a ele (Apêndice I, II e III). Além disso, para uma melhor visualização das possibilidades, foram gerados dois gráficos com os dados de saída: um que evidencia a evolução do salário líquido ao longo da sua vida já descontando o aporte mensal para investimento, Figura 1, e outro, que apresenta na Figura 2 o montante de capital acumulado no período. Os consultores, então, fizeram uma análise dos resultados das planilhas e apresentaram a João para que ele refletisse qual seria a melhor estratégia para sua vida. Os consultores deram também um parecer de qual seria a melhor alternativa, mas, deixaram claro que a decisão dependia dele e do esforço que ele estava disposto a fazer para atingir aquela condição. 
Em todos os cenários, como é possível perceber na Figura 2, dos 25 aos 60 anos seria a fase de acumulação do capital, proveniente da renda ativa, que seria necessário para subsidiar a renda passiva no período pós-emprego. Nota-se que a acumulação do capital para os Cenários 1 e 2 são próximas, sendo que no Cenário 2 é necessário reservar um pouco mais de recursos do que no Cenário 1. Já o Cenário 3, no qual o montante de capital investido se mantém na perpetuidade, necessitará de mais esforço por parte de João, pois é preciso reservar um percentual maior para o acúmulo de capital, resultando em um salário líquido menor na fase de renda ativa. Observando o gráfico da Figura 1 percebe-se que João, aos 60 anos, terá três possibilidades de usufruir de sua renda passiva pós-emprego, cada uma requerendo um percentual diferente do salário da fase ativa para a formação do capital. No Cenário 1 João começa a gozar de uma renda passiva que se reduz ao longo do tempo, assim como o seu capital, que chegará a zero aos seus 80 anos de idade, como pode ser observado no gráfico da Figura 2. Assim, a partir dessa idade ele não poderá contar com a renda passiva. Contudo, neste cenário, João terá um esforço menor de poupança, pois irá destinar mensalmente 13,8\% do seu salário para a formação do montante de capital requerido.

Caso ele não se sinta confortável com a diminuição da sua renda passiva ao longo dos anos, ele poderá fazer a opção de manter uma renda passiva constante, igual ao seu último salário líquido na fase ativa, como mostra a curva do Cenário 2 apresentada na Figura 1, porém, consumindo o seu capital aos poucos até chegar aos 80 anos, conforme evidencia a curva da evolução do capital pela idade do Cenário 2 da Figura 2. A partir desse ponto, o atual estudante não terá mais recursos para subsidiar sua renda passiva caso ele viva por mais tempo. Para atingir este objetivo, João precisará poupar mensalmente $16,0 \%$ do seu salário da fase ativa. Um aumento de 2,2 pontos percentuais em relação à primeira alternativa.

O Cenário 3 apresenta uma outra opção, para que João não se preocupe com a sua expectativa de vida e mantenha a sua renda passiva e o seu montante de capital independente de quantos anos viva no pós-emprego. Neste caso, João teria que destinar 23,3\% do seu salário da fase ativa para acumular o montante necessário e por isso teria um salário líquido médio mensal menor do que no Cenário 2, conforme é apresentado na Figura 1, mas teria uma segurança de ter uma renda passiva mensal independente da sua expectativa de vida, pois dessa forma atingiria um capital acumulado suficiente para garantir sua renda apenas com os juros, preservando o montante de capital na perpetuidade. Contudo, essa alternativa tem um preço e João necessitará aumentar em 9,5 pontos percentuais a destinação dos seus recursos mensais para investimento em relação ao Cenário 1 e 7,3 pontos percentuais em relação ao Cenário 2. 
Figura 1 - Salário Líquido e renda ao longo da vida, para os três cenários.

Salário líquido e renda ao longo da vida para os três cenários

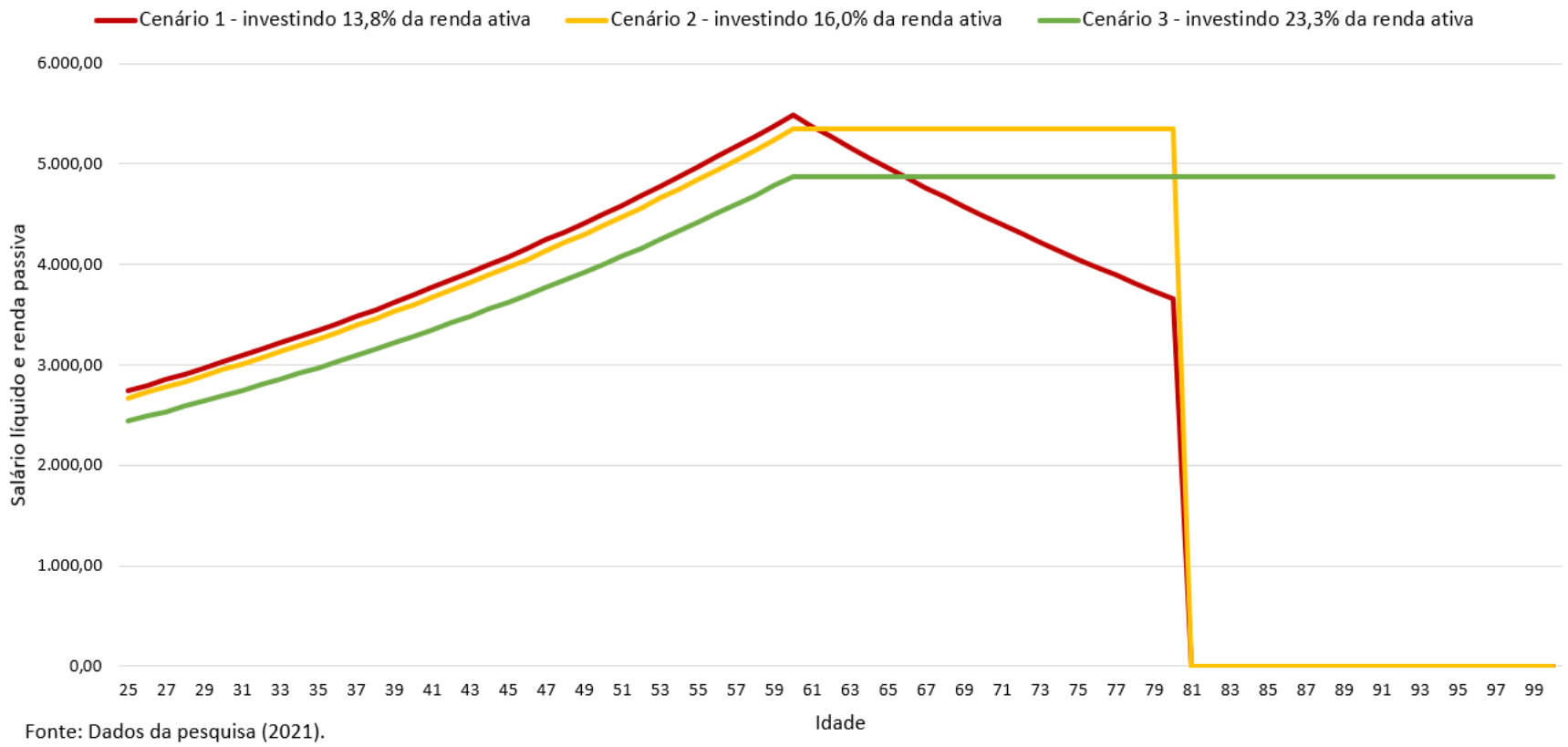

Figura 2 - Montante de capital acumulado ao longo dos anos.

Montante de capital acumulado ao longo dos anos

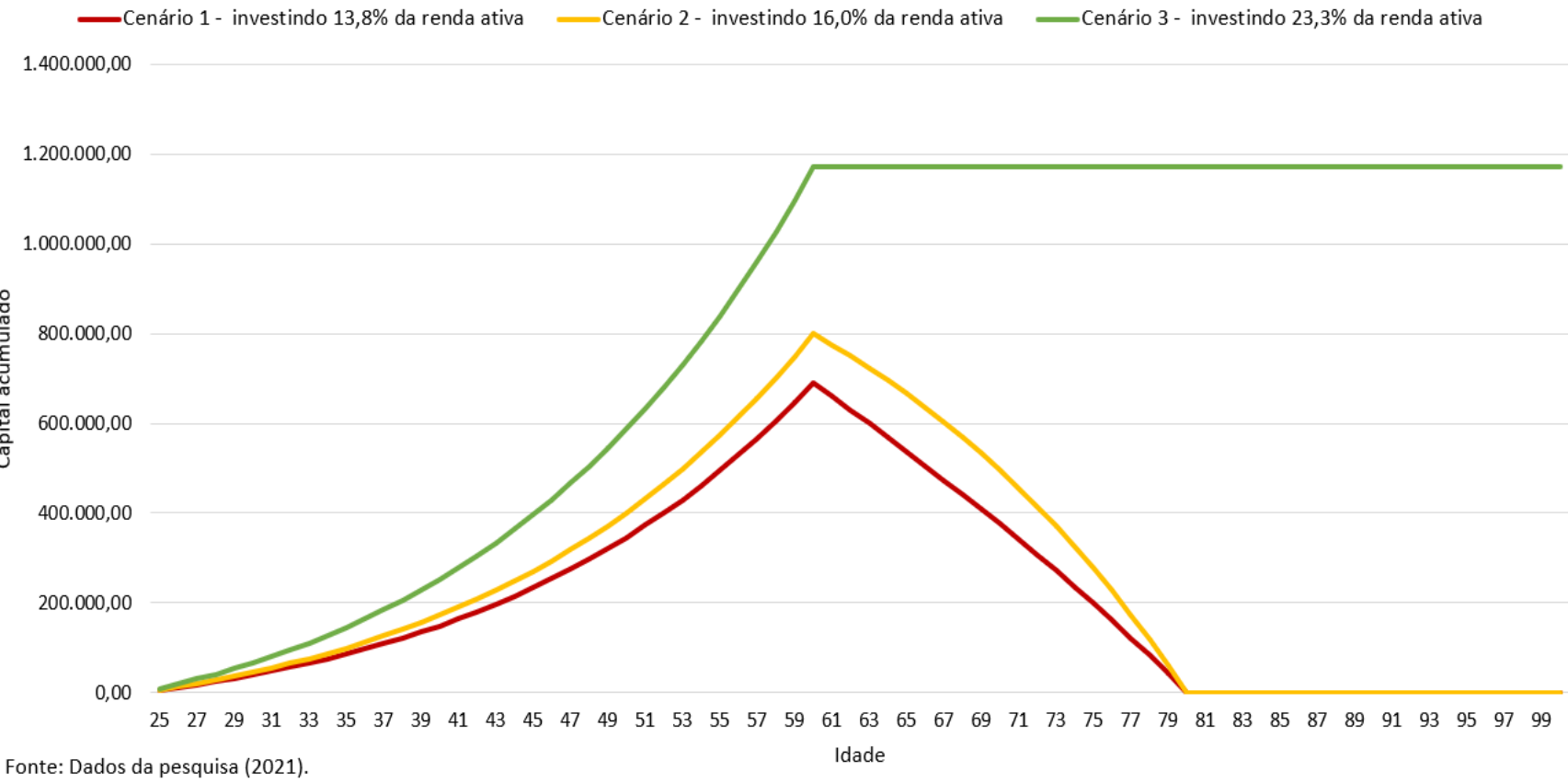

Percebe-se que o Cenário 3 seria ideal para dar segurança na fase pós-emprego, contudo, este cenário exige um esforço maior na fase ativa. João agora terá que avaliar os seus gastos e elaborar o seu planejamento financeiro para decidir qual opção mais se adequa ao seu estilo 
de vida e seus objetivos para o futuro. João também tem a possibilidade de reavaliar as premissas e fazer novas simulações, seja alterando a idade para se aposentar, alterando a taxa média de progressão da renda ativa ou alterando a expectativa de vida, pois tais premissas tem grande influência no percentual mensal a ser destinado a formação do capital.

Além disso, após traçar o plano, será necessário acompanhar seu desempenho ao longo da trajetória, fazendo os ajustes necessários ao longo do tempo e corrigindo as variações que certamente ocorrerão, como por exemplo necessidade de fazer uma retirada de emergência, realização de um aporte de capital devido ao recebimento de uma herança, venda de ativos com lucros acima do esperado, ou alteração na taxa média de retorno que pode variar com as circunstâncias da economia. Para isso basta utilizar a planilha, que já está preparada para este acompanhamento, colocando a idade atual e o valor já acumulado no campo de "aporte inicial".

\section{PROPOSTAS DE ENSINO}

\subsection{Fontes e métodos de coleta}

Este caso de ensino aborda de uma situação hipotética e a sua elaboração foi baseada em referências bibliográficas selecionadas e validadas para a construção do caso. O conhecimento prévio dos autores sobre o tema também foi utilizado para a construção das ideias e discussões aqui propostas.

\subsection{Objetivo de ensino}

Este trabalho objetiva propiciar uma reflexão acerca da importância de um planejamento financeiro de longo prazo, visando uma renda passiva sustentada por retorno de investimentos proveniente de uma gestão própria de recursos. Neste cenário, o público alvo foi estabelecido aos jovens que estão iniciando a vida profissional e permitindo um debate sobre finanças pessoais, mas não se limitando a eles.

\subsection{Utilização recomendada}

O caso foi elaborado para utilização em cursos de graduação e pode ser aplicado a diversas disciplinas que abordem temas relacionados a finanças, investimentos e planejamento orçamentário, sendo aplicável também em atividades interdisciplinares. Assim, espera-se que o caso aqui desenvolvido traga contribuições relevantes para a formação profissional dos alunos por meio de discussões e reflexões levantadas sobre o tema.

\subsection{Atividade Aberta}

Sugere-se que o caso aqui apresentado seja passado aos alunos por meio de uma atividade discursiva em grupo de no máximo cinco alunos com o objetivo de serem apresentadas propostas e soluções para que o personagem João possa passar a viver de renda passiva aos 60 anos de idade. Nesta atividade o aluno deverá abordar o planejamento a ser adotado por João, na aplicação de seus recursos financeiros, de forma a alcançar o objetivo final, que é a 
renda passiva após uma idade determinada. Além disso, serão apresentados três cenários para discussão e os alunos deverão apresentar qual cenário escolheriam para João, bem como os seus motivos e considerações a respeito dessa escolha. Os cenários abordados deverão ser os descritos no item 04 deste texto. Na sequência são apresentadas duas questões que podem ser utilizadas para estimular a reflexão sobre o caso.

1) Considerando os dados de entrada apresentados na tabela 02 , discuta como as variações nestas premissas poderiam influenciar no esforço que João terá que fazer para poupar recursos e atingir o objetivo.

2) Com base nos gráficos apresentados nas Figuras 01 e 02 discuta qual seria o cenário ideal para João, apresentando uma ponderação em relação a todos os cenários.

\section{ANÁLISE DO CASO COMO SUPORTE A LITERATURA}

O aumento da longevidade, cada vez mais, motiva as pessoas na busca de uma qualidade de vida melhor. Nessa perspectiva, é cada vez mais frequente a preocupação dos indivíduos em constituírem uma reserva financeira, além daquela proporcionada pela Previdência Social obrigatória, com o intuito de favorecer o atendimento do aumento das demandas econômicas devido à promoção da saúde, bem estar e qualidade de vida em idades mais avançadas. Contudo, os investimentos feitos ao longo tempo muitas vezes são insuficientes e falta um melhor planejamento para alcançar recursos que consigam garantir uma aposentadoria adequada. Muitas vezes, há uma resistência das pessoas mais novas em economizar para a velhice, todavia estudos mostram que quanto mais cedo se inicia esse processo menor deverá ser o esforço mensal. Assim, quanto antes se iniciar o planejamento financeiro para a aposentadoria, melhores serão os resultados alcançados. Outro ponto é que o dinheiro que será aplicado nestes casos é valioso e construir um portfólio de investimentos com diversificação é importante para que, no caso de eventuais perdas com determinada aplicação, tenha uma compensação com ganhos em outro tipo de investimento. O tipo de investimento escolhido pelo investidor que busca acumular recursos para uma aposentadoria tranquila depende da idade com a qual começa a poupar e investir. Quando jovem, o investidor pode assumir um perfil mais agressivo e investir em aplicações com maiores riscos, como investimentos em renda variável; porém, quanto mais perto da aposentadoria, maior é a necessidade do investidor migrar para investimentos mais conservadores, como a renda fixa.

Segundo França (2014) as pesquisas sobre preparação para aposentadoria dependem de mudanças comportamentais e motivacionais. Neste sentido se faz necessário que o indivíduo se organize e se dedique na construção de um projeto de envelhecimento ativo para potencializar a sua qualidade de vida, promovendo uma autonomia física e financeira. Além disso, será possível manter o seu bem-estar físico e mental ao longo de toda a sua vida e não só do período ativo. Segundo o autor, há uma lacuna de produções científicas que abordam o tema referente ao planejamento da aposentadoria por meio de investimentos. 
Segundo Dietrich (2016) a Previdência Social vem apresentando um resultado deficitário em suas contas ao longo dos anos, o que pode ser um grande motivador para as pessoas pensarem em outras formas de garantir recursos na velhice. Outro fator importante é que o Regime Geral de Previdência Social (RGPS) funciona pelo regime de repartição, na qual as contribuições efetuadas pagam o benefício de quem está aposentado hoje. Assim, os trabalhadores da ativa precisam que haja, no futuro, força ativa suficiente para contribuir para o pagamento do seu benefício. Neste sentido, se organizar financeiramente para não depender totalmente deste sistema pode ser um grande fator de convencimento para os jovens e montar uma estratégia diferenciada de investimento com vistas ao longo prazo. Portanto, quanto mais jovens os indivíduos mais favoráveis será assumir riscos em investimentos e garantir maiores retornos para uma segunda fase na qual se aconselha uma postura mais conservadora.

O artigo de Ongena e Zalewska (2018) reúne informações da literatura acadêmica sobre investidores individuais e institucionais a fim de compreender a natureza das dificuldades enfrentadas por eles. $\mathrm{O}$ texto relata as dificuldades encontradas pelos investidores nas suas decisões uma vez que a escolha do melhor investimento ao longo do tempo é sempre uma tarefa complicada e envolve diferentes variáveis. Além disso, as pessoas não tem se planejado para poupar o suficiente para a aposentadoria. Geralmente os recursos são alocados na caderneta de poupança na qual o retorno não é adequado para garantir uma renda confortável para um benefício pós-emprego.

Segundo Costa (2011), para a tomada de decisão das pessoas em relação aos tipos de investimentos, onde perdas podem acontecer, o fator confiança em quem endossa a proposta, pode ser um elemento importante. $\mathrm{O}$ estudo verifica se há impacto na decisão, sobre essa confiança. A abordagem foi focada no mercado de ações, e uma classificação foi realizada em relação aos endossantes, com diferentes níveis de confiança. Após análises relacionadas às atitudes do investidor, ao controle comportamental, as normas, e aos tipos de riscos, um questionário foi oferecido aos participantes, a fim de medir qual foi o verdadeiro peso das suas tomadas de decisão, de acordo com a confiança passada pelo endossante do investimento

\section{CONSIDERAÇÕES FINAIS}

Neste caso de ensino foi apresentado a história de João, estudante do último ano de Ciências Contábeis, que deseja acumular um montante de capital suficiente para lhe proporcionar uma futura renda passiva pós-emprego, sustentada por retorno de investimentos com recursos provenientes de uma gestão própria. $\mathrm{O}$ estudo aqui apresentado contou com o desenvolvimento de uma planilha, que poderá ser utilizada no caso de ensino, construída por meio de cálculos iterativos via código VBA do Excel. Para facilitar a análise dos dados, dois gráficos, um com a evolução de renda e outro com a evolução do capital, resumem os resultados apresentados.

O planejamento financeiro e a destinação de parte do salário para os investimentos não são tarefas fáceis, mas é preciso pensar no futuro e ter uma visão de longo prazo para alcançar uma situação que favoreça a qualidade de vida no pós-emprego e, para isso, não se deve depender apenas do sistema de seguridade social oferecido pelo governo, sendo então 
necessário lançar mão de outras possibilidades e uma delas é acumular um montante de capital durante a fase ativa da vida para gerar uma renda passiva no futuro.

Neste trabalho foram apresentados 3 cenários ao personagem João para se chegar a este objetivo. Percebe-se que o Cenário 1 seria o menos indicado devido à redução da renda e do capital ao longo do tempo. Nesta situação, corre-se o risco de não conseguir se manter devido ao aumento do custo de vida e a possibilidade de aumento da necessidade de mais recursos financeiros para subsidiar a terceira idade. Vale ainda pontuar que ele ainda vai ter os seus recursos limitados aos 80 anos de idade, e a partir daí ele não poderá mais contar com nenhum recurso próprio. O Cenário 2, intermediário, mantém-se o salário fixo até a idade estipulada no plano, sendo que a partir daí o seu capital e o seu recurso mensal também chegarão a zero.

O Cenário 3, então, seria o ideal, no qual se mantém ao longo da vida um salário líquido médio um pouco menor do que nos Cenários 1 e 2, mas garante-se renda e capital de forma perpétua. A questão então fica em decidir fazer um esforço maior ou menor para se atingir o objetivo e isso pode ser feito por meio de um planejamento financeiro adequado e disciplina. O importante é buscar a escolha de um cenário que apresente um esforço de poupança compatível com a realidade financeira da pessoa, para que não haja frustração e uma provável desistência precoce do plano estabelecido, qualquer que seja ele.

A estrutura da planilha foi idealizada para permitir a simulação de diversos cenários, bastando para isso mudar as premissas estabelecidas e realizar uma nova simulação, possibilitando a análise e comparação entre diferentes situações propostas. Ou seja, construiuse um recurso que é adaptativo aos objetivos de cada pessoa, bastando que ela os defina com clareza e estude, então, qual seria o melhor plano para o seu contexto.

Neste sentido, foi proposta uma atividade para ser realizada com alunos de cursos de graduação com disciplinas que abordem a temática de planejamento financeiro, aposentadoria e investimentos. Com a abordagem didática, será possível mobilizar a comunidade acadêmica quanto à reflexão sobre o tema, levando os alunos a um processo de análise crítica sobre a situação do personagem e também levando o conhecimento e conscientização sobre os benefícios de um planejamento financeiro de longo prazo.

Como proposta de continuidade do caso, sugere-se alterar a "regra dos 80" para a idade de início do recebimento da renda passiva, desta forma, neste momento, todo o montante de capital acumulado estaria direcionado para a modalidade de renda fixa, diminuindo muito os riscos no período pós-emprego, porém, será necessário realizar um estudo para verificar o impacto dessa mudança em relação ao alcance da taxa média de retorno. 


\section{REFERÊNCIAS}

B3. Brasil, Bolsa, Balcão, c2021. Página inicial. Disponível em: <http://www.b3.com.br/pt_br/>. Acesso em: 04 de março de 2021.

CALADO, Luiz Roberto Calado; MIRANDA, Mauro; AMARAL, Tânia Raquel dos Santos. BRAGA, Vicente Piccoli Medeiros; NARDINI, Ricardo. Instrumentos de Renda Variável e Renda Fixa, Material de Estudos da Certificação CPA-10. AMBIMA - 2018. Disponível em:<https://www.anbima.com.br/pt_br/educar/certificacoes/cpa-10/material-deestudos/material-de-estudos-cpa-10.htm> . Acesso em: 04 de março de 2021.

CAMARGO, Harion. Apostila Investimentos (Versão 1.2). Disponível em: < https://www.harioncamargo.com/pdf/apostila_investimentos_porHarionCamargo.pdf >. Acesso em: 04 de março de 2021.

COSTA, R. S.; FREITAS, H. O papel da confiança do decisor no processo decisório em um contexto de risco. In: $8^{\circ}$ Congresso Internacional de Gestão de Tecnologia e Sistemas de Informação - CONTECSI, 2011, São Paulo/SP. Anais do $8^{\circ}$ Congresso Internacional de Gestão de Tecnologia e Sistemas de Informação - CONTECSI, 2011.

DIRETRICH, J.; BRAIDO G. M.; CERUTTI, B. B. Planejamento financeiro pessoal para a aposentadoria: um estudo com estudantes de cursos de especialização, XIX Simpósio de Administração da Produção, Logística e Operações Internacionais - SIMPOI 2016, São Paulo, p. 1-17, 01 AGO 2016.

FRANÇA, C. L; MURTA, S. G.; IGLESIAS, Fabio. Planejamento da aposentadoria: uma escala de mudança de comportamento. Revista Brasileira de Orientação Profissional, São Paulo, v. 15, n. 1, p. 75-84, 01 JUN 2014.

IBGE. Agência IBGE Notícias. Em 2019, expectativa de vida era de 76,6 anos. Editoria: Estatísticas Sociais. Disponível em: <https://agenciadenoticias.ibge.gov.br/agencia-sala-deimprensa/2013-agencia-de-noticias/releases/29502-em-2019-expectativa-de-vida-era-de-766-anos>. Acesso em: 09 de maio de 2021.

MONEYTIMES. Money Times. Regra dos 80/20: o que é isso? c2021. Disponível em: <https://www.moneytimes.com.br/regra-dos-80-20-o-que-eisso/\#: : text=A\%20regra $\% 20 \mathrm{dos} \% 2080 \% 20$ funciona $\% 20 \mathrm{da} \% 20$ seguinte $\% 20$ forma $\% 3 \mathrm{~A} \% 2$ 0para\%20utiliz\%C3\%A1,ser\%20aplicado\%20em\%20renda\%20vari\%C3\%A1vel.> Acesso em: 09 de maio de 2021.

ONGENA, S.; ZALEWSKA, A. Institutional and individual investors: Saving for old age. Journal of Banking and Finance, Elservier, v. 92 , p. 257-268, 20 OUT 2018.

XP Investimentos. Expert XP, c2021. Página inicial. Disponível em: <https://conteudos.xpi.com.br/ 
Apêndice I - Planilha de cálculo do Cenário 1

\begin{tabular}{|c|c|c|c|c|c|c|c|c|}
\hline \multicolumn{4}{|c|}{ Idade para iniciar o plano para aposentadoria: } & 25 & & & & \\
\hline \multicolumn{4}{|c|}{ Idade para aposentar: } & 60 & & & & \\
\hline \multicolumn{4}{|c|}{ Expectativa de vida: } & 80 & & & & \\
\hline \multicolumn{4}{|c|}{ Reserva de Emergência (meses): } & 6 & & & & \\
\hline \multicolumn{4}{|c|}{ Taxa média de retorno esperada (a.a.): } & $5,0 \%$ & & & & \\
\hline \multicolumn{4}{|c|}{$\begin{array}{r}\text { Aporte inicial: } \\
\end{array}$} & 0,00 & & & & \\
\hline \multicolumn{4}{|c|}{ salário líquido inicial: } & $3.180,46$ & & & & \\
\hline \multicolumn{4}{|c|}{ Taxa atualização renda (a.a.): } & $2,0 \%$ & & & & \\
\hline \multicolumn{4}{|c|}{$\%$ da renda a ser aplicada: } & $13,8 \%$ & & & & \\
\hline \multirow[b]{2}{*}{ Idade } & \multirow{2}{*}{$\begin{array}{l}\text { salário líquido após } \\
\text { retirada de } 13,8 \% \text { ou } \\
\text { retirada mensal após } \\
\text { aposentadoria [R\$] }\end{array}$} & & & RE (Reserva & & Investi & imentos & \\
\hline & & $\begin{array}{c}\text { Aplicação anual } \\
\text { [R\$] }\end{array}$ & $\begin{array}{c}\text { Total Acumulado ao } \\
\text { final do período } \\
\text { [R\$] }\end{array}$ & $\begin{array}{c}\text { emergencial) aplicada } \\
\text { com liquidez diária } \\
\text { [R\$] }\end{array}$ & $\%$ RF & $\begin{array}{c}\text { Aplicação RF } \\
\text { [R\$] }\end{array}$ & $\begin{array}{c}\% \text { RV } \\
\text { (perspectiva de } \\
\text { vida - idade) }\end{array}$ & $\begin{array}{c}\text { Aplicação RV } \\
\text { [R\$] }\end{array}$ \\
\hline 25 & $2.742,81$ & $5.251,86$ & $5.514,45$ & $5.514,45$ & $0 \%$ & 0,00 & $0 \%$ & 0,00 \\
\hline 26 & $2.797,66$ & $5.356,90$ & $11.414,91$ & $11.414,91$ & $0 \%$ & 0,00 & $0 \%$ & 0,00 \\
\hline 27 & $2.853,61$ & $5.464,03$ & $17.722,90$ & $17.722,90$ & $0 \%$ & 0,00 & $0 \%$ & 0,00 \\
\hline 28 & $2.910,69$ & $5.573,31$ & $24.461,02$ & $20.250,78$ & $48 \%$ & $2.020,92$ & $52 \%$ & $2.189,33$ \\
\hline 29 & $2.968,90$ & $5.684,78$ & $31.653,09$ & $20.655,79$ & $49 \%$ & $5.388,68$ & $51 \%$ & $5.608,62$ \\
\hline 30 & $3.028,28$ & $5.798,48$ & $39.324,15$ & $21.068,91$ & $50 \%$ & $9.127,62$ & $50 \%$ & $9.127,62$ \\
\hline 31 & $3.088,84$ & $5.914,45$ & $47.500,52$ & $21.490,29$ & $51 \%$ & $13.265,22$ & $49 \%$ & $12.745,01$ \\
\hline 32 & $3.150,62$ & $6.032,73$ & $56.209,92$ & $21.920,09$ & $52 \%$ & $17.830,71$ & $48 \%$ & $16.459,12$ \\
\hline 33 & $3.213,63$ & $6.153,39$ & $65.481,47$ & $22.358,49$ & $53 \%$ & $22.855,18$ & $47 \%$ & $20.267,80$ \\
\hline 34 & $3.277,91$ & $6.276,46$ & $75.345,83$ & $22.805,66$ & $54 \%$ & $28.371,69$ & $46 \%$ & $24.168,47$ \\
\hline 35 & $3.343,46$ & $6.401,99$ & $85.835,20$ & $23.261,78$ & $55 \%$ & $34.415,38$ & $45 \%$ & $28.158,04$ \\
\hline 36 & $3.410,33$ & $6.530,03$ & $96.983,49$ & $23.727,01$ & $56 \%$ & $41.023,63$ & $44 \%$ & $32.232,85$ \\
\hline 37 & $3.478,54$ & $6.660,63$ & $108.826,32$ & $24.201,55$ & $57 \%$ & $48.236,12$ & $43 \%$ & $36.388,65$ \\
\hline 38 & $3.548,11$ & $6.793,84$ & $121.401,17$ & $24.685,58$ & $58 \%$ & $56.095,04$ & $42 \%$ & $40.620,55$ \\
\hline 39 & $3.619,07$ & $6.929,72$ & $134.747,43$ & $25.179,30$ & $59 \%$ & $64.645,20$ & $41 \%$ & $44.922,94$ \\
\hline 40 & $3.691,45$ & $7.068,31$ & $148.906,53$ & $25.682,88$ & $60 \%$ & $73.934,19$ & $40 \%$ & $49.289,46$ \\
\hline 41 & $3.765,28$ & $7.209,68$ & $163.922,02$ & $26.196,54$ & $61 \%$ & $84.012,54$ & $39 \%$ & $53.712,94$ \\
\hline 42 & $3.840,59$ & $7.353,87$ & $179.839,68$ & $26.720,47$ & $62 \%$ & $94.933,91$ & $38 \%$ & $58.185,30$ \\
\hline 43 & $3.917,40$ & $7.500,95$ & $196.707,66$ & $27.254,88$ & $63 \%$ & $106.755,25$ & $37 \%$ & $62.697,53$ \\
\hline 44 & $3.995,75$ & $7.650,97$ & $214.576,56$ & $27.799,98$ & $64 \%$ & $119.537,01$ & $36 \%$ & $67.239,57$ \\
\hline 45 & $4.075,66$ & $7.803,99$ & $233.499,57$ & $28.355,98$ & $65 \%$ & $133.343,33$ & $35 \%$ & $71.800,26$ \\
\hline 46 & $4.157,18$ & $7.960,07$ & $253.532,61$ & $28.923,10$ & $66 \%$ & $148.242,28$ & $34 \%$ & $76.367,24$ \\
\hline 47 & $4.240,32$ & $8.119,27$ & $274.734,48$ & $29.501,56$ & $67 \%$ & $164.306,05$ & $33 \%$ & $80.926,86$ \\
\hline 48 & $4.325,13$ & $8.281,65$ & $297.166,93$ & $30.091,59$ & $68 \%$ & $181.611,23$ & $32 \%$ & $85.464,11$ \\
\hline 49 & $4.411,63$ & $8.447,28$ & $320.894,93$ & $30.693,42$ & $69 \%$ & $200.239,04$ & $31 \%$ & $89.962,47$ \\
\hline 50 & $4.499,86$ & $8.616,23$ & $345.986,72$ & $31.307,29$ & $70 \%$ & $220.275,60$ & $30 \%$ & $94.403,83$ \\
\hline 51 & $4.589,86$ & $8.788,56$ & $372.514,04$ & $31.933,44$ & $71 \%$ & $241.812,23$ & $29 \%$ & $98.768,37$ \\
\hline 52 & $4.681,66$ & $8.964,33$ & $400.552,28$ & $32.572,10$ & $72 \%$ & $264.945,73$ & $28 \%$ & $103.034,45$ \\
\hline 53 & $4.775,29$ & $9.143,61$ & $430.180,69$ & $33.223,55$ & $73 \%$ & $289.778,71$ & $27 \%$ & $107.178,43$ \\
\hline 54 & $4.870,80$ & $9.326,49$ & $461.482,53$ & $33.888,02$ & $74 \%$ & $316.419,94$ & $26 \%$ & $111.174,57$ \\
\hline 55 & $4.968,21$ & $9.513,01$ & $494.545,33$ & $34.565,78$ & $75 \%$ & $344.984,66$ & $25 \%$ & $114.994,89$ \\
\hline 56 & $5.067,58$ & $9.703,28$ & $529.461,03$ & $35.257,09$ & $76 \%$ & $375.594,99$ & $24 \%$ & $118.608,94$ \\
\hline 57 & $5.168,93$ & $9.897,34$ & $566.326,29$ & $35.962,24$ & $77 \%$ & $408.380,32$ & $23 \%$ & $121.983,73$ \\
\hline 58 & $5.272,31$ & $10.095,29$ & $605.242,66$ & $36.681,48$ & $78 \%$ & $443.477,72$ & $22 \%$ & $125.083,46$ \\
\hline 59 & $5.377,75$ & $10.297,19$ & $646.316,84$ & $37.415,11$ & $79 \%$ & $481.032,37$ & $21 \%$ & $127.869,36$ \\
\hline 60 & $5.485,31$ & $10.503,14$ & $689.660,98$ & $38.163,41$ & $80 \%$ & $521.198,05$ & $20 \%$ & $130.299,51$ \\
\hline 61 & $5.375,60$ & 0,00 & $659.636,81$ & $32.253,61$ & $81 \%$ & $508.180,40$ & $19 \%$ & $119.202,81$ \\
\hline 62 & $5.268,09$ & 0,00 & $629.401,58$ & $31.608,53$ & $82 \%$ & $490.190,30$ & $18 \%$ & $107.602,75$ \\
\hline 63 & $5.162,73$ & 0,00 & $598.918,94$ & $30.976,36$ & $83 \%$ & $471.392,33$ & $17 \%$ & $96.550,24$ \\
\hline 64 & $5.059,47$ & 0,00 & $568.151,21$ & $30.356,84$ & $84 \%$ & $451.747,27$ & $16 \%$ & $86.047,10$ \\
\hline 65 & $4.958,28$ & 0,00 & $537.059,37$ & $29.749,70$ & $85 \%$ & $431.213,22$ & $15 \%$ & $76.096,45$ \\
\hline 66 & $4.859,12$ & 0,00 & $505.602,92$ & $29.154,71$ & $86 \%$ & $409.745,47$ & $14 \%$ & $66.702,75$ \\
\hline 67 & $4.761,94$ & 0,00 & $473.739,85$ & $28.571,61$ & $87 \%$ & $387.296,36$ & $13 \%$ & $57.871,87$ \\
\hline 68 & $4.666,70$ & 0,00 & $441.426,48$ & $28.000,18$ & $88 \%$ & $363.815,14$ & $12 \%$ & $49.611,16$ \\
\hline 69 & $4.573,36$ & 0,00 & $408.617,45$ & $27.440,18$ & $89 \%$ & $339.247,78$ & $11 \%$ & $41.929,50$ \\
\hline 70 & $4.481,90$ & 0,00 & $375.265,58$ & $26.891,37$ & $90 \%$ & $313.536,79$ & $10 \%$ & $34.837,42$ \\
\hline 71 & $4.392,26$ & 0,00 & $341.321,77$ & $26.353,55$ & $91 \%$ & $286.621,08$ & $9 \%$ & $28.347,14$ \\
\hline 72 & $4.304,41$ & 0,00 & $306.734,91$ & $25.826,47$ & $92 \%$ & $258.435,76$ & $8 \%$ & $22.472,67$ \\
\hline 73 & $4.218,32$ & 0,00 & $271.451,76$ & $25.309,94$ & $93 \%$ & $228.911,89$ & $7 \%$ & $17.229,93$ \\
\hline 74 & $4.133,96$ & 0,00 & $235.416,86$ & $24.803,75$ & $94 \%$ & $197.976,33$ & $6 \%$ & $12.636,79$ \\
\hline 75 & $4.051,28$ & 0,00 & $198.572,36$ & $24.307,67$ & $95 \%$ & $165.551,46$ & $5 \%$ & $8.713,23$ \\
\hline 76 & $3.970,25$ & 0,00 & $160.857,94$ & $23.821,52$ & $96 \%$ & $131.554,97$ & $4 \%$ & $5.481,46$ \\
\hline 77 & $3.890,85$ & 0,00 & $122.210,67$ & $23.345,09$ & $97 \%$ & $95.899,61$ & $3 \%$ & $2.965,97$ \\
\hline 78 & $3.813,03$ & 0,00 & $82.564,83$ & $22.878,19$ & $98 \%$ & $58.492,91$ & $2 \%$ & $1.193,73$ \\
\hline 79 & $3.736,77$ & 0,00 & $41.851,83$ & $22.420,62$ & 99\% & $19.236,89$ & $1 \%$ & 194,31 \\
\hline 80 & $3.662,03$ & 0,00 & 0,00 & 0,00 & $0 \%$ & 0,00 & $0 \%$ & 0,00 \\
\hline
\end{tabular}


Apêndice II - Planilha de cálculo do Cenário 2

\begin{tabular}{|c|c|c|c|c|c|c|c|c|}
\hline \multicolumn{4}{|c|}{ Idade para iniciar o plano para aposentadoria: } & 25 & & & & \\
\hline \multicolumn{4}{|c|}{ Idade para aposentar: } & 60 & & & & \\
\hline \multicolumn{4}{|c|}{ Expectativa de vida: } & 80 & & & & \\
\hline \multicolumn{4}{|c|}{ Reserva de Emergência (meses): } & 6 & & & & \\
\hline \multicolumn{4}{|c|}{ Taxa média de retorno esperada (а.а.): } & $5,0 \%$ & & & & \\
\hline \multicolumn{4}{|c|}{ Aporte inicial: } & 0,00 & & & & \\
\hline \multicolumn{4}{|c|}{ salário líquido inicial: } & $3.180,46$ & & & & \\
\hline \multicolumn{4}{|c|}{ Taxa atualização renda (a.a.): } & $2,0 \%$ & & & & \\
\hline \multicolumn{4}{|c|}{ \% da renda a ser aplicada: } & $16,0 \%$ & & & & \\
\hline \multirow[b]{2}{*}{ Idade } & \multirow{2}{*}{$\begin{array}{l}\text { salário líquido após } \\
\text { retirada de } 16 \% \text { ou } \\
\text { retirada mensal após } \\
\text { aposentadoria [R\$] }\end{array}$} & & & RE (Reserva & & Investi & imentos & \\
\hline & & $\begin{array}{c}\text { Aplicação anual } \\
\text { [R\$] }\end{array}$ & $\begin{array}{c}\text { final do período } \\
{[R \$]}\end{array}$ & $\begin{array}{c}\text { emergencial) aplicada } \\
\text { com liquidez diária } \\
\text { [R\$] }\end{array}$ & $\%$ RF & $\begin{array}{c}\text { Aplicação RF } \\
\text { [R\$] }\end{array}$ & $\begin{array}{c}\% \text { RV } \\
\text { (perspectiva de } \\
\text { vida - idade) }\end{array}$ & $\begin{array}{c}\text { Aplicação RV } \\
\text { [R\$] }\end{array}$ \\
\hline 25 & $2.673,12$ & $6.088,05$ & $6.392,46$ & $6.392,46$ & $0 \%$ & 0,00 & $0 \%$ & 0,00 \\
\hline 26 & $2.726,58$ & $6.209,82$ & $13.232,39$ & $13.232,39$ & $0 \%$ & 0,00 & $0 \%$ & 0,00 \\
\hline 27 & $2.781,12$ & $6.334,01$ & $20.544,72$ & $19.853,70$ & $47 \%$ & 324,78 & $53 \%$ & 366,24 \\
\hline 28 & $2.836,74$ & $6.460,69$ & $28.355,68$ & $20.250,78$ & $48 \%$ & $3.890,35$ & $52 \%$ & $4.214,55$ \\
\hline 29 & $2.893,47$ & $6.589,91$ & $36.692,86$ & $20.655,79$ & $49 \%$ & $7.858,16$ & $51 \%$ & $8.178,91$ \\
\hline 30 & $2.951,34$ & $6.721,70$ & $45.585,30$ & $21.068,91$ & $50 \%$ & $12.258,19$ & $50 \%$ & $12.258,19$ \\
\hline 31 & $3.010,37$ & $6.856,14$ & $55.063,51$ & $21.490,29$ & $51 \%$ & $17.122,34$ & $49 \%$ & $16.450,88$ \\
\hline 32 & $3.070,58$ & $6.993,26$ & $65.159,60$ & $21.920,09$ & $52 \%$ & $22.484,55$ & $48 \%$ & $20.754,97$ \\
\hline 33 & $3.131,99$ & $7.133,13$ & $75.907,37$ & $22.358,49$ & $53 \%$ & $28.380,90$ & $47 \%$ & $25.167,97$ \\
\hline 34 & $3.194,63$ & $7.275,79$ & $87.342,31$ & $22.805,66$ & $54 \%$ & $34.849,79$ & $46 \%$ & $29.686,86$ \\
\hline 35 & $3.258,52$ & $7.421,30$ & $99.501,80$ & $23.261,78$ & $55 \%$ & $41.932,01$ & $45 \%$ & $34.308,01$ \\
\hline 36 & $3.323,69$ & $7.569,73$ & $112.425,10$ & $23.727,01$ & $56 \%$ & $49.670,93$ & $44 \%$ & $39.027,16$ \\
\hline 37 & $3.390,17$ & $7.721,12$ & $126.153,54$ & $24.201,55$ & $57 \%$ & $58.112,63$ & $43 \%$ & $43.839,35$ \\
\hline 38 & $3.457,97$ & $7.875,55$ & $140.730,54$ & $24.685,58$ & $58 \%$ & $67.306,08$ & $42 \%$ & $48.738,88$ \\
\hline 39 & $3.527,13$ & $8.033,06$ & $156.201,78$ & $25.179,30$ & $59 \%$ & $77.303,27$ & $41 \%$ & $53.719,22$ \\
\hline 40 & $3.597,67$ & $8.193,72$ & $172.615,28$ & $25.682,88$ & $60 \%$ & $88.159,44$ & $40 \%$ & $58.772,96$ \\
\hline 41 & $3.669,62$ & $8.357,59$ & $190.021,51$ & $26.196,54$ & $61 \%$ & $99.933,23$ & $39 \%$ & $63.891,74$ \\
\hline 42 & $3.743,02$ & $8.524,75$ & $208.473,57$ & $26.720,47$ & $62 \%$ & $112.686,92$ & $38 \%$ & $69.066,18$ \\
\hline 43 & $3.817,88$ & $8.695,24$ & $228.027,25$ & $27.254,88$ & $63 \%$ & $126.486,59$ & $37 \%$ & $74.285,78$ \\
\hline 44 & $3.894,23$ & $8.869,15$ & $248.741,22$ & $27.799,98$ & $64 \%$ & $141.402,39$ & $36 \%$ & $79.538,85$ \\
\hline 45 & $3.972,12$ & $9.046,53$ & $270.677,13$ & $28.355,98$ & $65 \%$ & $157.508,75$ & $35 \%$ & $84.812,40$ \\
\hline 46 & $4.051,56$ & $9.227,46$ & $293.899,82$ & $28.923,10$ & $66 \%$ & $174.884,64$ & $34 \%$ & $90.092,09$ \\
\hline 47 & $4.132,59$ & $9.412,01$ & $318.477,42$ & $29.501,56$ & $67 \%$ & $193.613,83$ & $33 \%$ & $95.362,03$ \\
\hline 48 & $4.215,24$ & $9.600,25$ & $344.481,55$ & $30.091,59$ & $68 \%$ & $213.785,17$ & $32 \%$ & $100.604,79$ \\
\hline 49 & $4.299,55$ & $9.792,25$ & $371.987,50$ & $30.693,42$ & $69 \%$ & $235.492,91$ & $31 \%$ & $105.801,16$ \\
\hline 50 & $4.385,54$ & $9.988,10$ & $401.074,37$ & $31.307,29$ & $70 \%$ & $258.836,96$ & $30 \%$ & $110.930,12$ \\
\hline 51 & $4.473,25$ & $10.187,86$ & $431.825,35$ & $31.933,44$ & $71 \%$ & $283.923,26$ & $29 \%$ & $115.968,65$ \\
\hline 52 & $4.562,72$ & $10.391,62$ & $464.327,81$ & $32.572,10$ & $72 \%$ & $310.864,11$ & $28 \%$ & $120.891,60$ \\
\hline 53 & $4.653,97$ & $10.599,45$ & $498.673,62$ & $33.223,55$ & $73 \%$ & $339.778,56$ & $27 \%$ & $125.671,52$ \\
\hline 54 & $4.747,05$ & $10.811,44$ & $534.959,32$ & $33.888,02$ & $74 \%$ & $370.792,76$ & $26 \%$ & $130.278,54$ \\
\hline 55 & $4.841,99$ & $11.027,67$ & $573.286,33$ & $34.565,78$ & $75 \%$ & $404.040,42$ & $25 \%$ & $134.680,14$ \\
\hline 56 & $4.938,83$ & $11.248,22$ & $613.761,28$ & $35.257,09$ & $76 \%$ & $439.663,18$ & $24 \%$ & $138.841,00$ \\
\hline 57 & $5.037,61$ & $11.473,19$ & $656.496,19$ & $35.962,24$ & $77 \%$ & $477.811,14$ & $23 \%$ & $142.722,81$ \\
\hline 58 & $5.138,36$ & $11.702,65$ & $701.608,78$ & $36.681,48$ & $78 \%$ & $518.643,29$ & $22 \%$ & $146.284,01$ \\
\hline 59 & $5.241,13$ & $11.936,70$ & $749.222,76$ & $37.415,11$ & $79 \%$ & $562.328,04$ & $21 \%$ & $149.479,61$ \\
\hline 60 & $5.345,95$ & $12.175,44$ & $799.468,10$ & $38.163,41$ & $80 \%$ & $609.043,75$ & $20 \%$ & $152.260,94$ \\
\hline 61 & $5.345,95$ & 0,00 & $775.290,12$ & $32.075,69$ & $81 \%$ & $602.003,68$ & $19 \%$ & $141.210,74$ \\
\hline 62 & $5.345,95$ & 0,00 & $749.903,23$ & $32.075,69$ & $82 \%$ & $588.618,58$ & $18 \%$ & $129.208,96$ \\
\hline 63 & $5.345,95$ & 0,00 & $723.247,01$ & $32.075,69$ & $83 \%$ & $573.672,19$ & $17 \%$ & $117.499,12$ \\
\hline 64 & $5.345,95$ & 0,00 & $695.257,97$ & $32.075,69$ & $84 \%$ & $557.073,11$ & $16 \%$ & $106.109,16$ \\
\hline 65 & $5.345,95$ & 0,00 & $665.869,48$ & $32.075,69$ & $85 \%$ & $538.724,72$ & $15 \%$ & $95.069,07$ \\
\hline 66 & $5.345,95$ & 0,00 & $635.011,56$ & $32.075,69$ & $86 \%$ & $518.524,85$ & $14 \%$ & $84.411,02$ \\
\hline 67 & $5.345,95$ & 0,00 & $602.610,75$ & $32.075,69$ & $87 \%$ & $496.365,50$ & $13 \%$ & $74.169,56$ \\
\hline 68 & $5.345,95$ & 0,00 & $568.589,90$ & $32.075,69$ & $88 \%$ & $472.132,50$ & $12 \%$ & $64.381,70$ \\
\hline 69 & $5.345,95$ & 0,00 & $532.868,01$ & $32.075,69$ & $89 \%$ & $445.705,16$ & $11 \%$ & $55.087,15$ \\
\hline 70 & $5.345,95$ & 0,00 & $495.360,02$ & $32.075,69$ & $90 \%$ & $416.955,89$ & $10 \%$ & $46.328,43$ \\
\hline 71 & $5.345,95$ & 0,00 & $455.976,63$ & $32.075,69$ & $91 \%$ & $385.749,85$ & $9 \%$ & $38.151,08$ \\
\hline 72 & $5.345,95$ & 0,00 & $414.624,08$ & $32.075,69$ & $92 \%$ & $351.944,51$ & $8 \%$ & $30.603,87$ \\
\hline 73 & $5.345,95$ & 0,00 & $371.203,89$ & $32.075,69$ & $93 \%$ & $315.389,22$ & $7 \%$ & $23.738,97$ \\
\hline 74 & $5.345,95$ & 0,00 & $325.612,70$ & $32.075,69$ & $94 \%$ & $275.924,78$ & $6 \%$ & $17.612,22$ \\
\hline 75 & $5.345,95$ & 0,00 & $277.741,94$ & $32.075,69$ & $95 \%$ & $233.382,94$ & $5 \%$ & $12.283,31$ \\
\hline 76 & $5.345,95$ & 0,00 & $227.477,65$ & $32.075,69$ & $96 \%$ & $187.585,88$ & $4 \%$ & $7.816,08$ \\
\hline 77 & $5.345,95$ & 0,00 & $174.700,14$ & $32.075,69$ & $97 \%$ & $138.345,72$ & $3 \%$ & $4.278,73$ \\
\hline 78 & $5.345,95$ & 0,00 & $119.283,76$ & $32.075,69$ & $98 \%$ & $85.463,91$ & $2 \%$ & $1.744,16$ \\
\hline 79 & $5.345,95$ & 0,00 & $61.096,56$ & $32.075,69$ & $99 \%$ & $28.730,66$ & $1 \%$ & 290,21 \\
\hline 80 & $5.345,95$ & 0,00 & 0,00 & 0,00 & $0 \%$ & 0,00 & $0 \%$ & 0,00 \\
\hline
\end{tabular}


Apêndice III - Planilha de cálculo do Cenário 3

\begin{tabular}{|c|c|c|c|c|c|c|c|c|}
\hline \multicolumn{4}{|c|}{ Idade para iniciar o plano para aposentadoria: } & 25 & & & & \\
\hline \multicolumn{4}{|c|}{ Idade para aposentar: } & 60 & & & & \\
\hline \multicolumn{4}{|c|}{ Expectativa de vida: } & 80 & & & & \\
\hline \multicolumn{4}{|c|}{ Reserva de Emergência (meses): } & 6 & & & & \\
\hline \multicolumn{4}{|c|}{ Taxa média de retorno esperada (a.a.): } & $5,0 \%$ & & & & \\
\hline \multicolumn{4}{|c|}{ Aporte inicial: } & 0,00 & & & & \\
\hline \multicolumn{4}{|c|}{ salário líquido inicial: } & $3.180,46$ & & & & \\
\hline \multicolumn{4}{|c|}{ Taxa atualização renda (а.а.): } & $2,0 \%$ & & & & \\
\hline \multicolumn{4}{|c|}{ \% da renda a ser aplicada: } & $23,3 \%$ & & & & \\
\hline \multirow[b]{2}{*}{ Idade } & \multirow{2}{*}{$\begin{array}{l}\text { salário líquido após } \\
\text { retirada de } 23,3 \% \text { ou } \\
\text { retirada mensal após } \\
\text { aposentadoria [R\$] }\end{array}$} & & & RE (Reserva & & Investi & imentos & \\
\hline & & $\begin{array}{c}\text { Aplicação anual } \\
\text { [R\$] }\end{array}$ & $\begin{array}{c}\text { Total Acumulado ao } \\
\text { final do período } \\
\text { [R\$] }\end{array}$ & $\begin{array}{c}\text { emergencial) aplicada } \\
\text { com liquidez diária } \\
\text { [R\$] }\end{array}$ & $\%$ RF & $\begin{array}{c}\text { Aplicação RF } \\
\text { [R\$] }\end{array}$ & $\begin{array}{c}\text { \% RV } \\
\text { (perspectiva de } \\
\text { vida - idade) }\end{array}$ & $\begin{array}{c}\text { Aplicação RV } \\
\text { [R\$] }\end{array}$ \\
\hline 25 & $2.437,90$ & $8.910,68$ & $9.356,22$ & $9.356,22$ & $0 \%$ & 0,00 & $0 \%$ & 0,00 \\
\hline 26 & $2.486,66$ & $9.088,90$ & $19.367,37$ & $19.367,37$ & $0 \%$ & 0,00 & $0 \%$ & 0,00 \\
\hline 27 & $2.536,39$ & $9.270,68$ & $30.069,95$ & $19.853,70$ & $47 \%$ & $4.801,64$ & $53 \%$ & $5.414,61$ \\
\hline 28 & $2.587,12$ & $9.456,09$ & $41.502,34$ & $20.250,78$ & $48 \%$ & $10.200,75$ & $52 \%$ & $11.050,81$ \\
\hline 29 & $2.638,86$ & $9.645,21$ & $53.704,93$ & $20.655,79$ & $49 \%$ & $16.194,08$ & $51 \%$ & $16.855,06$ \\
\hline 30 & $2.691,64$ & $9.838,12$ & $66.720,20$ & $21.068,91$ & $50 \%$ & $22.825,65$ & $50 \%$ & $22.825,65$ \\
\hline 31 & $2.745,47$ & $10.034,88$ & $80.592,83$ & $21.490,29$ & $51 \%$ & $30.142,30$ & $49 \%$ & $28.960,25$ \\
\hline 32 & $2.800,38$ & $10.235,58$ & $95.369,83$ & $21.920,09$ & $52 \%$ & $38.193,86$ & $48 \%$ & $35.255,87$ \\
\hline 33 & $2.856,39$ & $10.440,29$ & $111.100,62$ & $22.358,49$ & $53 \%$ & $47.033,33$ & $47 \%$ & $41.708,80$ \\
\hline 34 & $2.913,52$ & $10.649,09$ & $127.837,20$ & $22.805,66$ & $54 \%$ & $56.717,03$ & $46 \%$ & $48.314,51$ \\
\hline 35 & $2.971,79$ & $10.862,07$ & $145.634,24$ & $23.261,78$ & $55 \%$ & $67.304,85$ & $45 \%$ & $55.067,61$ \\
\hline 36 & $3.031,23$ & $11.079,32$ & $164.549,23$ & $23.727,01$ & $56 \%$ & $78.860,44$ & $44 \%$ & $61.961,78$ \\
\hline 37 & $3.091,85$ & $11.300,90$ & $184.642,64$ & $24.201,55$ & $57 \%$ & $91.451,42$ & $43 \%$ & $68.989,67$ \\
\hline 38 & $3.153,69$ & $11.526,92$ & $205.978,04$ & $24.685,58$ & $58 \%$ & $105.149,62$ & $42 \%$ & $76.142,83$ \\
\hline 39 & $3.216,76$ & $11.757,46$ & $228.622,27$ & $25.179,30$ & $59 \%$ & $120.031,36$ & $41 \%$ & $83.411,62$ \\
\hline 40 & $3.281,10$ & $11.992,61$ & $252.645,62$ & $25.682,88$ & $60 \%$ & $136.177,65$ & $40 \%$ & $90.785,10$ \\
\hline 41 & $3.346,72$ & $12.232,46$ & $278.121,99$ & $26.196,54$ & $61 \%$ & $153.674,52$ & $39 \%$ & $98.250,93$ \\
\hline 42 & $3.413,65$ & $12.477,11$ & $305.129,05$ & $26.720,47$ & $62 \%$ & $172.613,32$ & $38 \%$ & $105.795,26$ \\
\hline 43 & $3.481,93$ & $12.726,65$ & $333.748,49$ & $27.254,88$ & $63 \%$ & $193.090,97$ & $37 \%$ & $113.402,64$ \\
\hline 44 & $3.551,56$ & $12.981,18$ & $364.066,16$ & $27.799,98$ & $64 \%$ & $215.210,36$ & $36 \%$ & $121.055,83$ \\
\hline 45 & $3.622,60$ & $13.240,81$ & $396.172,32$ & $28.355,98$ & $65 \%$ & $239.080,62$ & $35 \%$ & $128.735,72$ \\
\hline 46 & $3.695,05$ & $13.505,62$ & $430.161,84$ & $28.923,10$ & $66 \%$ & $264.817,57$ & $34 \%$ & $136.421,17$ \\
\hline 47 & $3.768,95$ & $13.775,74$ & $466.134,45$ & $29.501,56$ & $67 \%$ & $292.544,04$ & $33 \%$ & $144.088,85$ \\
\hline 48 & $3.844,33$ & $14.051,25$ & $504.194,99$ & $30.091,59$ & $68 \%$ & $322.390,31$ & $32 \%$ & $151.713,09$ \\
\hline 49 & $3.921,21$ & $14.332,28$ & $544.453,63$ & $30.693,42$ & $69 \%$ & $354.494,54$ & $31 \%$ & $159.265,66$ \\
\hline 50 & $3.999,64$ & $14.618,92$ & $587.026,18$ & $31.307,29$ & $70 \%$ & $389.003,22$ & $30 \%$ & $166.715,67$ \\
\hline 51 & $4.079,63$ & $14.911,30$ & $632.034,35$ & $31.933,44$ & $71 \%$ & $426.071,65$ & $29 \%$ & $174.029,27$ \\
\hline 52 & $4.161,22$ & $15.209,53$ & $679.606,08$ & $32.572,10$ & $72 \%$ & $465.864,46$ & $28 \%$ & $181.169,51$ \\
\hline 53 & $4.244,45$ & $15.513,72$ & $729.875,78$ & $33.223,55$ & $73 \%$ & $508.556,13$ & $27 \%$ & $188.096,10$ \\
\hline 54 & $4.329,34$ & $15.823,99$ & $782.984,76$ & $33.888,02$ & $74 \%$ & $554.331,59$ & $26 \%$ & $194.765,15$ \\
\hline 55 & $4.415,92$ & $16.140,47$ & $839.081,50$ & $34.565,78$ & $75 \%$ & $603.386,79$ & $25 \%$ & $201.128,93$ \\
\hline 56 & $4.504,24$ & $16.463,28$ & $898.322,02$ & $35.257,09$ & $76 \%$ & $655.929,34$ & $24 \%$ & $207.135,58$ \\
\hline 57 & $4.594,33$ & $16.792,55$ & $960.870,29$ & $35.962,24$ & $77 \%$ & $712.179,20$ & $23 \%$ & $212.728,85$ \\
\hline 58 & $4.686,21$ & $17.128,40$ & $1.026 .898,62$ & $36.681,48$ & $78 \%$ & $772.369,37$ & $22 \%$ & $217.847,77$ \\
\hline 59 & $4.779,94$ & $17.470,97$ & $1.096 .588,07$ & $37.415,11$ & $79 \%$ & $836.746,64$ & $21 \%$ & $222.426,32$ \\
\hline 60 & $4.875,54$ & $17.820,38$ & $1.170 .128,87$ & $38.163,41$ & $80 \%$ & $905.572,37$ & $20 \%$ & $226.393,09$ \\
\hline 61 & $4.875,54$ & 0,00 & $1.170 .128,88$ & $29.253,22$ & $81 \%$ & $924.109,28$ & $19 \%$ & $216.766,38$ \\
\hline 62 & $4.875,54$ & 0,00 & $1.170 .128,88$ & $29.253,22$ & $82 \%$ & $935.518,04$ & $18 \%$ & $205.357,62$ \\
\hline 63 & $4.875,54$ & 0,00 & $1.170 .128,89$ & $29.253,22$ & $83 \%$ & $946.926,80$ & $17 \%$ & $193.948,86$ \\
\hline 64 & $4.875,54$ & 0,00 & $1.170 .128,89$ & $29.253,22$ & $84 \%$ & $958.335,56$ & $16 \%$ & $182.540,11$ \\
\hline 65 & $4.875,54$ & 0,00 & $1.170 .128,90$ & $29.253,22$ & $85 \%$ & $969.744,32$ & $15 \%$ & $171.131,35$ \\
\hline 66 & $4.875,54$ & 0,00 & $1.170 .128,90$ & $29.253,22$ & $86 \%$ & $981.153,09$ & $14 \%$ & $159.722,60$ \\
\hline 67 & $4.875,54$ & 0,00 & $1.170 .128,91$ & $29.253,22$ & $87 \%$ & $992.561,85$ & $13 \%$ & $148.313,84$ \\
\hline 68 & $4.875,54$ & 0,00 & $1.170 .128,91$ & $29.253,22$ & $88 \%$ & $1.003 .970,61$ & $12 \%$ & $136.905,08$ \\
\hline 69 & $4.875,54$ & 0,00 & $1.170 .128,92$ & $29.253,22$ & $89 \%$ & $1.015 .379,37$ & $11 \%$ & $125.496,33$ \\
\hline 70 & $4.875,54$ & 0,00 & $1.170 .128,92$ & $29.253,22$ & $90 \%$ & $1.026 .788,13$ & $10 \%$ & $114.087,57$ \\
\hline 71 & $4.875,54$ & 0,00 & $1.170 .128,93$ & $29.253,22$ & $91 \%$ & $1.038 .196,89$ & $9 \%$ & $102.678,81$ \\
\hline 72 & $4.875,54$ & 0,00 & $1.170 .128,94$ & $29.253,22$ & $92 \%$ & $1.049 .605,66$ & $8 \%$ & $91.270,06$ \\
\hline 73 & $4.875,54$ & 0,00 & $1.170 .128,94$ & $29.253,22$ & $93 \%$ & $1.061 .014,42$ & $7 \%$ & $79.861,30$ \\
\hline 74 & $4.875,54$ & 0,00 & $1.170 .128,95$ & $29.253,22$ & $94 \%$ & $1.072 .423,19$ & $6 \%$ & $68.452,54$ \\
\hline 75 & $4.875,54$ & 0,00 & $1.170 .128,96$ & $29.253,22$ & $95 \%$ & $1.083 .831,95$ & $5 \%$ & $57.043,79$ \\
\hline 76 & $4.875,54$ & 0,00 & $1.170 .128,96$ & $29.253,22$ & $96 \%$ & $1.095 .240,71$ & $4 \%$ & $45.635,03$ \\
\hline 77 & $4.875,54$ & 0,00 & $1.170 .128,97$ & $29.253,22$ & $97 \%$ & $1.106 .649,48$ & $3 \%$ & $34.226,27$ \\
\hline 78 & $4.875,54$ & 0,00 & $1.170 .128,98$ & $29.253,22$ & $98 \%$ & $1.118 .058,25$ & $2 \%$ & $22.817,52$ \\
\hline 79 & $4.875,54$ & 0,00 & $1.170 .128,99$ & $29.253,22$ & $99 \%$ & $1.129 .467,01$ & $1 \%$ & $11.408,76$ \\
\hline 80 & $4.875,54$ & 0,00 & $1.170 .129,00$ & $29.253,22$ & $100 \%$ & $1.140 .875,78$ & $0 \%$ & 0,00 \\
\hline
\end{tabular}

